\title{
Sára Czina
}

\section{The Role of Vilmos Tarján in the History of the Newyork Coffeehouse}

\begin{abstract}
The purpose of the study. To examine how the Newyork Coffeehouse was run between 1920 and 1936. What were Vilmos Tarján's, the executive board member and main shareholder's, business policies. What profile did he intend for the Coffeehouse? The Coffeehouses were struggling between the two World Wars. What were the Coffeehouse's solutions for the postWorld War challenges and the problems of the Great Depression?

Applied methods. To get to know the Newyork Coffeehouse Company Limited, the sources were the documents of the Company Registry. These helped to reconstruct the list of the shareholders. The balance and profit loss accounts were used to examine the profitability of the Coffeehouse. The problems of the Coffeehouses in Budapest between 1920 and 1936 were examined through the articles of professional journals. To understand Vilmos Tarján's aspirations, his own books and articles of the daily newspapers were used.

Outcomes. Vilmos Tarján wanted to turn the Newyork Coffeehouse into a luxorious, highend Coffeehouse. In order to reach this goal, he renovated the interior, later refurbished and modernized it several times. He established one of the best kitchen in the city and engaged the audience with frequent performances and concerts. With these aspirations he could solve the post-World War problems successfully. However, his skills and role in the associations of the industry were not enough to face the challenges that arose during the Great Depression.
\end{abstract}

Keywords: Budapest, Newyork Coffeehouse, Coffeehouse Culture, Company Limited, Vilmos Tarján

\section{Introduction}

The world of the coffeehouses shaped Budapest's cultural life and the lives of its residents at the turn of the nineteenth century. Apart from Dezső Kosztolányi, Ödön Gerő referred to Budapest as the "city of coffeehouses". According to him, "whoever wants to paint an image of the capital, paints his cafes," he says. The coffeehouses became one of Pest's most important public spaces at the turn of the century. The residents of Pest visited the coffeehouses to get away from the cramped living quarters of poor housing conditions or the bourgeoisie's exemplary, but repressive lodgings. ${ }^{2}$ They gathered information, read newspapers, played games, and had a good time there. ${ }^{3}$ However, the coffeehouse is not interesting only from a social and cultural perspective, but also from economic aspect, as a business.

The café culture of Budapest was influenced not only by the prestige of the prominent coffeehouses, but also by their sheer number. There are sources about the first coffee-seller in Pest in 1714. "Blázsó" ("Balázs the Coffeecooker") was a traveling coffee-maker at first, later he opened his own coffee house/coffee measurement. ${ }^{4}$ By 1737 we already know about the existence of three coffeehouses. "The Civil Coffeehouse Society of Pest", 6 the first professional association of the coffeehouse owners was founded in 1796. Its members merely formed an alliance to protect their own independence and financial interests. Industrial development and education have not

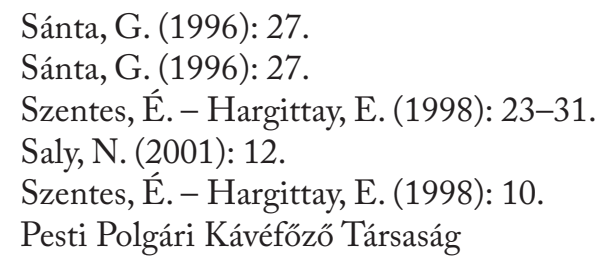


yet been considered to be their duty. ${ }^{7}$ These responsibilities were established by the "Budapest Coffee Association"s in 1793, one year after the Act of Industry was passed. ${ }^{9}$ The number of cafés gradually increased, in 1872 there were 93 coffeehouses in Pest. ${ }^{10}$ From 1873, the unification of Buda and Pest, this number increased rapidly, until 1896, this time the boom of the Millennium enabled the

The number of Coffeehouses in Budapest

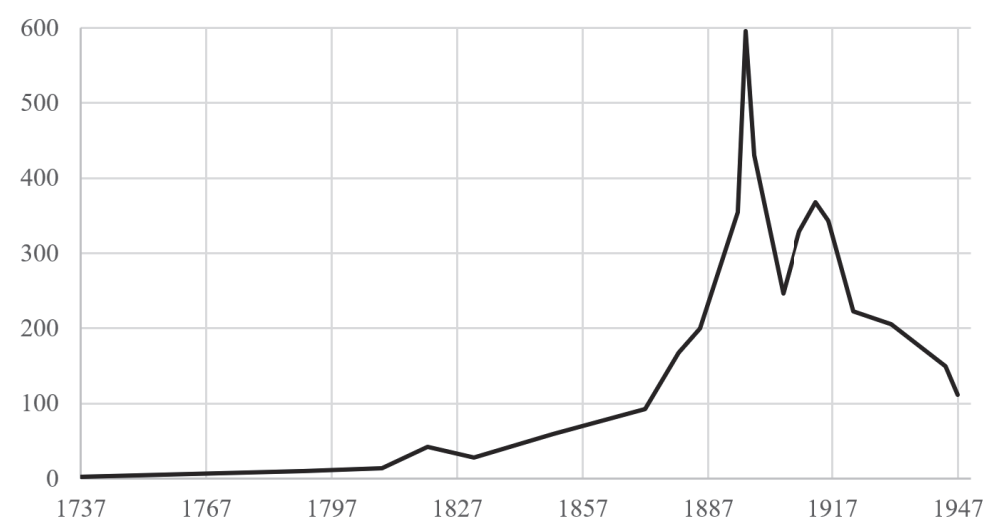

operation of 591 coffeehouses. ${ }^{11}$ However, after the Millenial year due to the deconjuncture, their numbers began to decline. ${ }^{12}$ The period from 1873 to the onset of the First World War is considered the culmination of coffeehouse culture. ${ }^{13}$ "There is no corner of the Hungarian capital that does not have a coffee house or a coffee measurement," states Mihály Pásztor in his novel, "Cifra Nyomorúság". ${ }^{14}$

Restrictions, ticket system, and supply problems typified the years during the First World War. It also had an impact on coffeehouses; they started employing women in place of the male labour force who was sent to the front, they used substitute raw materials, and sold their food and beverages in exchange for food ticket. There have been new sorts of taxes introduced, as well as new closure hours, and there were also difficulties with overhead services. ${ }^{15}$ Furthermore, less and less guests visited the coffeehouses, as they had no money, no time, and no mood to spend their time there. Despite this fact, 343 cafes remained open until the final year of the Great War, albeit their numbers continued to fall in the next years. The revolutions that erupted after the war, the epidemic of the Spanish flu and the general economic downturn, made it extremely difficult for the coffeehouses to survive. Just 223 of them persisted in 1922, and there had been two years when 200 coffeehouses remained standing. ${ }^{16}$ When it came to advancing the interests of the profession, the Budapest Coffee Association faced a challenging task in an era marked by postwar inflation and austerity, the Great Depression, professional dumping, and eventually growing tourism. ${ }^{17}$ We only have one data from the Second World War, which claims that 150 coffeehouses could maintain themselves in 1944, which had to close during the siege of Budapest. By 1947, 116 coffeehouses had opened their doors, but they could not have been existed for a long time. In 1949, due to the socialization, they had to be closed, and the citizens of Budapest were introduced to the not-so-new espressos. ${ }^{18}$

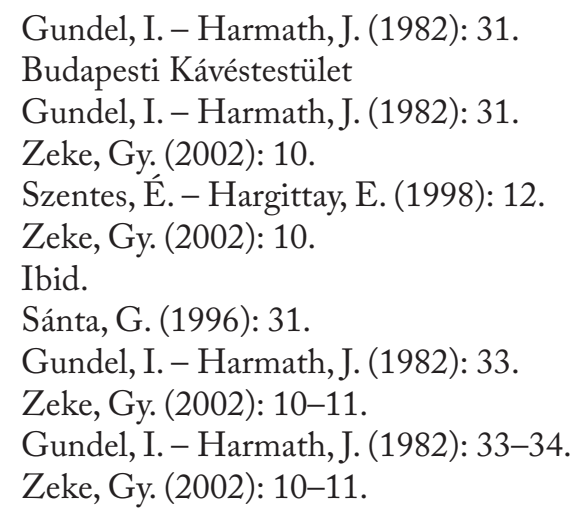


The Newyork Palace was built by the Hungarian headquarters of the Newyork Insurance Company just before the millennium (1894), at the peak of coffeehouse culture. ${ }^{19} \mathrm{With}$ this building, the American insurance company intended to demonstrate its wealth. Therefore, no financial limit was set at its design/construction..$^{20}$ Dr. Miksa Arányi, the Hungarian agent of the insurance firm, commissioned Alajos Hauszmann to design the palace, ${ }^{21}$ and he enlisted the help of Flóris Korb and Kálmán Giergl, the designers of the Széchenyi Bath and the Academy of Music. ${ }^{22}$ They designed the structure in the historicizing eclecticism style ${ }^{23}$ and had it decorated by notable artists of the time. ${ }^{24}$ The Newyork Coffeehouse was opened on the ground floor of this majestic building. The café is separated into the same number of levels as the building itself, which has four stories. They did not spare on the furnishings; the twisted marble columns, ornate railings, and Venetian chandeliers made the interior famous. It is not in vain, that the newspaper articles about the opening were songs of praise for the building. ${ }^{25}$

The opening ceremony was held on October 23, 1894, only two years after the construction began. Sándor Steuer was the first tenant, although he was unable to enter a profession in New York. Yet, at the time, this was the most important secret of successful and profitable coffeehouses. He gave the lease to the Harsányi brothers in 1900. They hired the experienced Gyula Reisz as a chief waiter, whose name was already known in literary circles. Because of the work of the three of them, Newyork became a literary coffeehouse, ${ }^{26}$ something that only one coffeehouse in a hundred could achieve. ${ }^{27}$ In 1913, however, the Harsányi brothers sold the coffeehouse. ${ }^{28}$ The New-York Coffeehouse Company Limited, Hungary's first Coffeehouse Corporation, was established at that time. If we look at stock fluctuations, we can split the history of the New-York Coffeehouse Company Limited into three broad periods (1913-1920, 1920-1936, 1937-1949), within which there are various smaller periods. ${ }^{29}$ The middle phase of the company was researched at, from 1920 to 1936, and also the role of Vilmos Tarján, its most significant shareholder and board member.

\section{Research Questions}

Vilmos Tarján and his three associates owned the coffeehouses shares from 1920 and $1936 . \mathrm{He}$ was also a member of the board of directors ${ }^{30}$ and was in charge of the company's operations. They took over the coffeehouse despite the challenging economic and social environment after the First World War and the revolutions. They owned the shares until 1936. My main research questions were:

- What was Vilmos Tarján's business policy, how he did wish to alter the business, and what profile he did intend for himself?

- How did he deal with the post-World War challenges, as well as the Great Depression?

19 Csapó, K. (1996): 177.

20 The Equipment was worth 250000 Ft.; Budapesti Hírlap: A Newyork-kávéház megnyitása, October 25., 1894;

Saly N. (2005): 39.

21 Csapó, K. (1996): 178.

22 Pesti Hírlap: A legszebb kávéház, October 25., 1894. 9., Vasárnapi Ujság: Newyork palota és kávéháza, 1894. nr. 46.: 764-765.

23 Csapó, K. (1996): 178.

24 Gusztáv Mannheimer, Ferenc Eisenhut, Gyula Donáth, Endre Thék

25 Pesti Napló: New-York Budapesten, October 14, 1894. 9.; Pesti Hírlap: A legszebb kávéház, October 25, 1895. 9.

26 Kálmán, J. (1965): 178-179.

27 Saly, N. (2014): 214-215.

Budapesti Hírlap: Új gazdák a Newyorkban, September 17, 1913. 9.

Czina, S. (2021): 97.

BFL. VII.2.e - Cg.2497 New York Kávéház - 1659. box 


\section{Vilmos Tarján}

Vilmos Tarján was a prominent figure in Budapest's public life in the first part of the twentieth century. He was born under the name of Vilmos Klein in Budapest on March 25, 1881. ${ }^{31}$ His parents were graters of Jewish descent, who went on to run a spice shop. He studied at the "Pesti fóreál" from 1890 to 1895, then at the Academy of Commerce, where he graduated in 1898. By this time, his aptitude for journalism had become obvious. He wanted to become a journalist a, but his parents did not let him, as journalism was not a profitable profession in those times. ${ }^{32}$ Instead of journalism, he pursued a commercial career that would provide him with financial security. He began his career with the Guttmann Brothers, a coal transportation company where he felt like a prisoner in the captivity of the monotonous and uninteresting days. He resigned soon after to work for the Wertheimer and Frankl Company, which specialized in colonial items. For him, the more colourful workplace was far more enjoyable. However, after two years of service, he quit since he was not permitted to serve as a traveling agent. ${ }^{33}$

He gave his parents every reason to be concerned after his resignation, as he had been sitting in café seats as an unemployed for months. He would have enjoyed this lifestyle if he had had enough money, but due to a shortage of it, he had to get a new job quickly. He decided to become a journalist. He contacted László Fényes, the editor-in-chief of "Magyarság”, a newly created newspaper, who saw his skill and hired him. ${ }^{34}$ This daily newspaper did not satisfy his ambitions. ${ }^{35}$ Thus, he went to the "Friss Ujság", and from there to the upscale Magyar Hírlap, where his ambition of becoming a "police reporter" finally came true. ${ }^{36}$ However, he departed the newspaper and the nation in 1910, when the chief of police filed charges against him, claiming that he had blackmailed the owner of the Maison Frida luxury brothel. ${ }^{37}$ These charges were never proven. He went to Berlin and was working for almost a year as the manager of the Passage Theatre. But he had to return home for a court hearing. ${ }^{38}$ Later on, he was working as a master of ceremonies in Budapest's nightlife for a while as a conference attendant when his friend Simon Kemény introduced him to Miklós Andor, the owner-editor-in-chief of the recently established newspaper, " $A z E s t$ " ${ }^{39}$

$\mathrm{Az}$ Est needed an experienced police reporter and Tarján needed a newspaper, thus they were fortunate to cross paths. Tarján reached the pinnacle of his journalistic success over the next ten years. It was then that he wrote his most significant articles, e.g., about the death of Elza the Magnate, he discussed the assassination in Sarajevo for the first time, or the outbreak of the First World War. ${ }^{40}$ Despite his professionalism, he made a crucial mistake. he was talking about politics in an article - a style which he consciously tried to avoid. ${ }^{41}$ He wrote a report on the beating of Béla Kun, that the public considered to be too forgiving. Because of the scandal that followed the article, he was fired from the newspaper, Az Est in 1920. During his entire life, Vilmos Tarján's main ambition was being a journalist, and until the end of his life referred to himself as a reporter. However, this blunder effectively ended his career. ${ }^{42}$

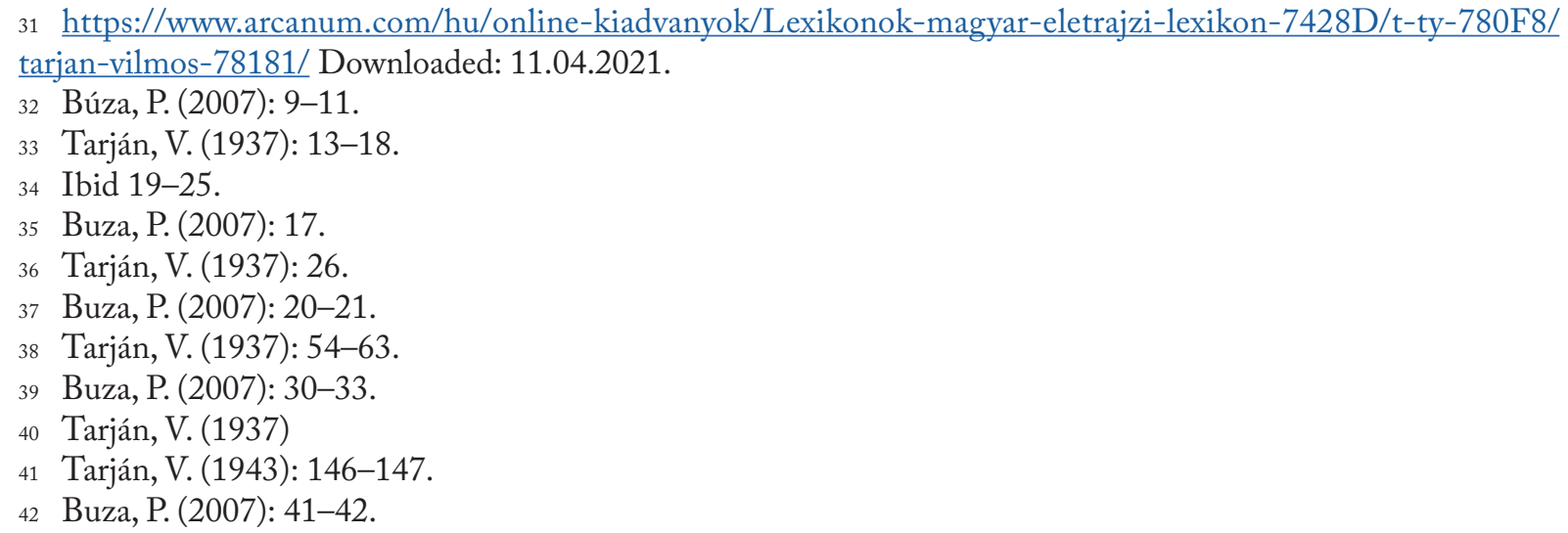


After a brief stay as a refugee in Vienna, he spent his days in the "Otthon-Kör", playing cards. He did not think he would need much money as a bachelor; therefore he was not looking for a new career. He did, however, play the cards professionally, winning a little amount of money every day. He looked for a new life when he had already made a profit of half a million korona. ${ }^{43}$ Tarján encouraged Miklós Magyar, his former peer in school, an influential city politician, to cooperate with him. ${ }^{44}$ They associated with Béla Zoltán, the Chief Treasurer of Weiss Manfréd Acél és Fémmúvei Rt, (who was the brother-in-law of Miklós Andor, the owner of the Newyork Palace), ${ }^{45}$ and Olga Herskovits, the descendant of a restaurant-owner dynasty. ${ }^{46}$ Tarján and his three partners bought the New York coffeehouse's lease. Being a coffeehouse owner was Tarján's life's second most significant period. For 16 years, the Newyork Coffeehouse was identified by his name as the "Tarján Works". ${ }^{47}$

\section{Sources}

The sources of the research are the documents of the Company Registry from the Budapest Archives, i.e. the minutes of the general meetings with all its attachments, the reports of the Executive and Supervisory Boards, the balance and profit and loss accounts, procurations and power of attorneys as well as the list of shareholders. The last one helps to write the list of the owners of the shares and to reconstruct the stock transfers. The almost complete list of the shareholders can be reconstructed. I supplemented the court documents with issues of "Kávésok Lapja" and "Magyar Kávésipar", ${ }^{48}$ in addition to the articles of the current daily newspapers. I supplemented these with Vilmos Tarján's four books ${ }^{49}$ and a guestbook from the Newyork Coffeehouse. ${ }^{50}$

\section{Development of Newyork Café Company Limites between 1920 and 1936}

The Haas family sold the Newyork Café Co. Ltd. to Vilmos Tarján and his associates in 1920. The identity of the four major shareholders was almost permanent until 1936. The most important shareholders were Vilmos Tarján, Béla Zoltán, Miklós Magyar, Olga Herskovits, his later wife. Only Miklós Magyar's name disappeared from the shareholder lists in 1934, when the problems of the coffeehouse became significant. There was a share migration in 1921 when five minority shareholders sold their stocks, which were bought by new inventors. Although there were changes among the owners of coffeehouse shares from 1921 to 1934, these changes were not significant. The majority of the coffeehouse shares were owned by the four major shareholders. These data suggest stability. Since 1934, when the coffeehouse had been loss-making for three years, there have been significant changes in the shareholder list. ${ }^{51}$

However, the number, nominal value, and currency of the shares all changed significantly. By 1923, the business had 375 shares with a nominal value of 400 korona, but by 1924, the 150,000 korona share capital had been enlarged to 15 million korona. As a result, 37,500 shares with a nominal value of 400 korona were issued, which the existing shareholders acquired. In addition to inflation and other economic difficulties, this share capital increase was also necessary due to

43 Tarján, V. (1937): 159-160.

44 Búza, P. (2007): 49.

45 Tarján, V. (1937): 161.

46 Csapó, K. (1996): 188.

47 Szentes, É. - Hargittay, E. (1998): 247.

48 The official journals of the A Budapesti Kávésipartársulat, a Budapesti Kávésok és a Budapesti Kávésok Szövetsége

49 Tarján, V. (1937), Tarján, V (1940), Tarján, V. (1943); Tarján, V. (2007)

50 Saly, N. (2016)

51 Czina, S. (2021): 101-102. 
the planned developments. ${ }^{52}$ The next change was due to the introduction of the pengó in 1926. The new share capital was 50,000 pengős, according to the initial balance sheet. According to the Article XVI. 7. $\$$ in 1920, the nominal value of a share could not be less than 10 pengös, therefore 5,000 shares with a nominal value of 10 pengős were issued. All previous 7.5 shares worth 1 share later. ${ }^{53}$ The share capital was enlarged again a year later, from 5,000 to 10,000 pengős. This was essential due to the planned reconstruction of the café on the one side, ${ }^{54}$ and the Adria Insurance Company's purchase of the Newyork Palace from the Az Est group, which wished to increase the home rent on the other significantly. The new stocks were bought in equal shares by the four major shareholders. ${ }^{55}$

\section{Business Purpose:}

Tarján's main goal was to transform the coffeehouse into an exquisite, sophisticated premium coffeehouse that catered to the most affluent customers. ${ }^{56}$ To accomplish so, they first conducted a six-week big clean-up, which included clearing unwelcome regulars who had become acclimated to the coffeehouse throughout World War I and the revolutions. ${ }^{57}$ There was no time or money at the time to completely restore the business. However, a restaurant was created in the "Mélyvíz" 58 and a bar was turned out of the basement. ${ }^{59}$ Five years later, at a cost of four billion koronas, a major transformation occurred (320,000 pengős). The Marble Hall and the Mahogany Bar were added to the restaurant, which became renowned among the elite as the "Newyork Bar". ${ }^{60}$ Tarján additionally refurbished the equipment, announcing grandeur by purchasing beautiful rugs and luxurious seats. ${ }^{61}$ Throughout Tarján's era, he was in charge of the coffeehouse exteriors, ensuring that it maintained its elegant appearance. After undergoing a comprehensive restoration in 1923, the coffeehouse was subject to another complete change in 1933. ${ }^{62}$ The competition among the coffeehouses of Budapest was intensifying. Because of that, Tarján replaced all the equipment to the last tablecloth, to impress the guests with a dazzling display of quality and elegance, and New York still being referred to as the most beautiful coffeehouse in the city.

The transformation of the coffeehouse into a café-restaurant was another major economic strategy. As a result, the conventional café menu was broadened to include hot dish, too. Since the 1910s, the citizens of Pest had been accustomed to being able to complete their entire dinner within the confines of a single coffeehouse. However, if Tarján wanted the Newyork to remain profitable, they had to adjust this necessity. „If you already bave a kitchen, let it be a kitchen, even a first-class, "Tarján believed, „I contracted the renowned gastronomy teacher, Istvann Varga, as a chef." 63 The Newyork quickly gained a reputation for its cuisine. For example, the "Bedo" Imbisz" ${ }^{64}$ was invented here, in honor of dr. Móricz Bedő. However, they were especially famous for

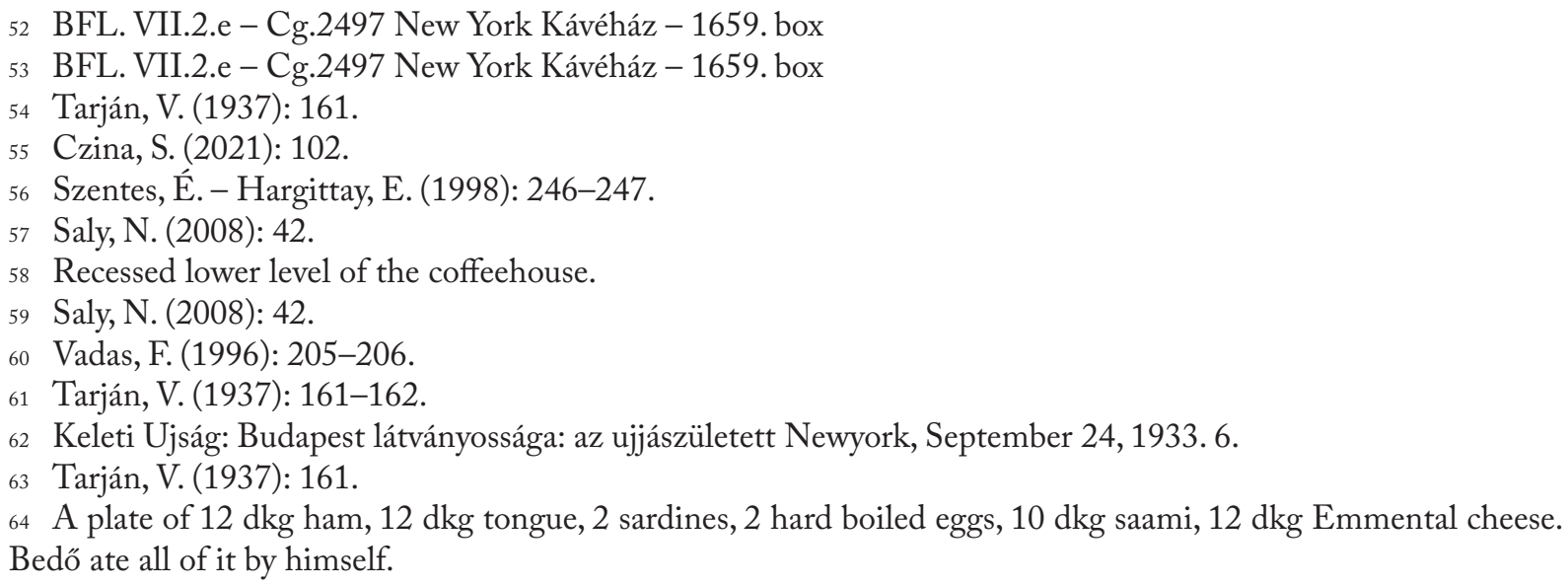


their soups. ${ }^{65}$ They named the Pethes soup in memory of actor Imre Pethes, or it was New Year's Eve when 2,000 servings of soup were served in a single night. ${ }^{66}$ Tarján was encouraged by his success and opened several restaurants ${ }^{67}$ in Budapest that were also profitable, but none of them lasted as long as the Newyork.

In addition to serving food, great emphasis was also placed on entertainment. At first, only music was played by Miklós Brodszky ${ }^{68}$ in the Newyork Bar. He was discovered by Tarján in a pub called "Szenesláda". He quickly came to popularity, with a daily plate income of roughly 300 koronas. ${ }^{69}$ Even during his time in New York, Brodszky began composing, which upset Tarján, who feared losing his star. His anxiety was justified, when a song Brodszky wrote for a guest (Richard Tauber) became a worldwide hit, prompting him to leave the coffeehouse. ${ }^{70}$ Later on, the crowd was entertained with bluett and cabaret performances. The first was the "Tsudabár", the parody of "Csodabár", which was staged at the Operett Theater at the time. ${ }^{71}$ Journalists have already reported on the main rehearsals, ${ }^{72}$ and Tarján discovered new stars and actresses. ${ }^{73}$ The audience was enthralled by these moments, and there were evenings, when seven princes appeared at the Newyork Bar. However, they stopped playing these pieces, because the investment did not pay off. ${ }^{74}$ Furthermore, the best bands have performed here. Teddy Sinclair, ${ }^{75}$ Saljapin, and other jazz bands ${ }^{76}$ were among the many foreign and Hungarian stars who performed here. From 1934 onwards, these concerts were routinely broadcast on radio throughout the country. ${ }^{77}$

He intended his personal network to play a major part in making the coffeehouse famous. In order to open a high-end coffeehouse, he went to see his friends at the National Casino, who had been promoting the Newyork's cuisine since their first visit as a customer. ${ }^{78}$ A guestbook from the Newyork Coffeehouses heyday has been discovered, with the autographs of 365 international and Hungarian celebrities. ${ }^{79}$ The old bohemian companions, in addition to the aristocracy, also found their place in the coffeehouse. Different people from the different layer of the society could have a good time in the different areas of the coffeehouse in the same time. Aristocrats and bank chairmans gathered in the Marble Room; the wealthier but no longer in the top ten thousand met in the Mélyvíz, while musicians and croupiers enjoyed themselves in the coffeehouse. ${ }^{80}$

\footnotetext{
65 Csapó, K. (1996): 191.

66 Magyarország: A legvidámabb szilveszter, January 3, 1928. 6.

${ }_{67}$ The restaurant of the Margitszigeti Nagyszálló, Felső Vendéglő, Parisien Grillt, Royal Orfeum, Papagáj Mulató, the restaurant of the Lukács Fürdő. (Tarján, V. (1937)

68 Miklós Brodszky: composer, conductor, musician, (Magyar Életrajzi Lexikon)

69 At the exit, a white plate was set on which the audience left a tip for the performer. This institution did not appeal to Tarján since he was concerned with the opinions of the visitors. It would be a pity if someone did not put the proper amount of money on the plate before he went. (Tarján, V. (1941): 37-38.)

70 Tarján, V (1937): 163.

71 Az Est: Ma estétôl kezdve egy színházzal több játszik Budapesten, October 2, 1930. 8.

72 Tarján, V. (1937): 163.

R., Margit; Mezey, Mária (Tarján, V. (1937): 164-165.)

Tarján, V. (1937): 163-164.

Magyarország, April 11, 1928. 11.

8 órai ujság: Kilenc vöröshaju görl autobuszon Budapest utcáin..., October 8, 1929. 10.

Pécsi Napló: A Pécsi Napló rádióműsora, April 11, 1930, 11.

Csapó, K. (1996): 188.

Saly, N. (2016): 23-25.

Tarján, V. (1937): 165
} 


\section{Answers to the Difficulties}

Tarján took over the coffeehouse in difficult times, ${ }^{81}$ following the First World War and the horrors of the Republic of Councils and Revolutions. A variety of complaints have been made about the economic conditions and prospects in the profession. The luxury tax ${ }^{82}$ the closing order ${ }^{83}$ the lack of commodities, ${ }^{84}$ and the overhead fees were the most significant.

Tarján and his associates took over the coffeehouse in 1920 at a loss of 100,000 koronas, but by December of that year, they had already paid a luxury tax of 150,000 koronas, indicating that they had made a considerable profit. They announced an 85,000 korona profit at the general meeting in December 1921. They were also able to pay dividends for the first time in the joint stock company's history ( 9,000 korona). ${ }^{85}$

During Tarján's leadership, the coffeehouse was subjected to a luxury tax. He paid the tax on his own until 1928, ${ }^{86}$ when he joined the newly founded "Budapest Coffeehouse Luxury and Sales Tax Community" ${ }^{87}$, which attempted to address the issue of tax payment on a community basis. ${ }^{88}$ Another 21 new taxes have been imposed on coffeehouses. ${ }^{89}$

Another crucial issue was the matter of the closing hour. In 1920, closing hours were still early all throughout town; coffeehouses had to close at 10 p.m., while restaurants had to close at 12 p.m. ${ }^{90}$ Tarján using his connections, got help from Prime Minister Károly Huszár, his friend, who promised to remedy the coffeehouse owner's problem. However, the case remained on National Chief Captain, Imre Nádossy's desk. Tarján made to keep the Newyork Coffeehouse open all night at the cost of several visits to Nádossy. ${ }^{91}$ They also attempted to resolve the issue of closing hours at the industrial association level, among others Tarján tried to force concessions from the authorities. ${ }^{92}$

The two most important problems were solved, and the coffeehouse remained profitable until 1931. The start of the loss corresponded with the Great Depression's spread into Hungary. In his reports of the Executive Board and autobiographical writings, Tarján also mentions its unique phenomenon as an explanation.

There was a common criticism at the meetings of the Budapest Coffee Association, that many coffeehouses kept their prices low in the hope of attracting as many customers as possible, which dropped the pricing in the industry. ${ }^{93}$ This was unsustainable and resulted in a significant increase in competition. On the other hand, the restaurant owners had similar feelings about the Coffeehouses, which supplied hot food and enticed people away from the restaurants. The position between the two industrial associations was contentious between the two world wars. ${ }^{94}$

In addition to the professional competition, the public's consumption capacity has decreased. The number of visitors dropped continuously, which was considerable, and their financial situation has worsened as a result of the crisis. ${ }^{95}$ Tarján compensated by booking even more

81 Kávésok Lapja: Beköszöntő, October 20, 1925. 1.

82 Magyar Kávésipar: A fényüzési adó és a kávéházak, July 1, 1920.1.

83 Magyar Kávésipar: A záróra, December 1, 1920.1.

84 Magyar Kávésipar: A Budapesti Kávésok Áruforgalmi Részvénytársaságának tőkeemelése, July 1, 1920. 3.

85 Czina, S. (2021): 102-103.

86 BFL. VII.2.e - Cg.2497 New York Kávéház - 1659. box

87 Budapesti Kávésok Fényűzési és Forgalmi Adóközössége

Kávésok Lapja: A budapesti kávésok fényűzési és forgalmi adóközössége megalakult, February1, 1928. 1.

Magyar Kávésipar: A kongresszus, November 15, 1925.3.

Magyar Kávésipar: A záróra, December 1, 1920.1.

Tarján, V. (1937): 167-171.

Magyar Kávésipar: A záróra, December 1.1920.2.

Kávésok Lapja: Elöljárósági ülés, December 1.1931.2.

Kávésok Lapja: Elöljárósági ülés, January 1, 1933. 2.

FL. VII.2.e - Cg.2497 New York Kávéház - 1659. box 
costly bands and serving a cheap menu. He was optimistic that these opportunities would excite the audience 's interest, but the visitors fell short. ${ }^{96}$ In addition to the economical crisis, the lifestyle of the people has also changed, which mostly expressed itself in other leisure activities. They did not spend entire days sitting at coffeehouses. ${ }^{97}$ Furthermore, the topic of professional dumping has been discussed at the Budapest Coffee Industry Association's presidency meeting since the early 1930s. There were far more cafes trying their luck than it was demanded. ${ }^{98}$

In 1932, Tarján in his report of the board of directors, lists the costs that cannot be reduced as another issue. These included taxes, electricity bills and other overheads, as well as the house rent. ${ }^{99}$ In the case of the Newyork Café, the issue of house rent is what the general public has been informed about by the press. The Newyork Palace was owned by the Est Group when Tarján and his associates took it over. In 1928, the Adria Insurance Company bought the building from them, and wanted to sign a new contract with the Coffeehouse, that would have increased the rent by 100\%. ${ }^{100}$ Tarján, on the other hand, refused to accept this and brought the case to court. ${ }^{101}$ A rent of 110,000 pengős were eventually agreed upon, but due to economic circumstances, it had to be decreased by $10 \%$ within two years. ${ }^{102}$ However, because the battle was still ongoing, the lowering of the house rent has been the subject of constant debate until 1936.

In his memoirs, Tarján also mentions a number of additional factors that contributed to the coffeehouse's downfall. The popularity of pubs, which attracted a substantial guest away from the coffeehouse, was a big dilemma. The Grand Boulevard's loss of prominence, he claimed, was a concern. The wealthy moved to Buda, while the bourgeois middle class migrated to Lipótváros. In addition, Nagymező Street and Oktogon became centers of nightlife. At the same time, it was impossible to rent an apartment at New York Palace. All of these factors have resulted in a decrease in the number of the customers. ${ }^{103}$

The public was already aware of the problems, as house rent conflicts were frequently reported in the press. The board of directors requested a moratorium from it's creditors in 1936, negotiated a private deal, and attempted to sell the coffeehouse as soon as possible. Menyhért Kraszner was the buyer. ${ }^{104}$

\section{Summary}

Tarján's business strategy was to open a high-end Coffeehouse, which he did successfully. To do this, he first renovated the café's furnishings and décor to fit the demands of affluent guests, and then he continued to change, modernize, and improve it. Second, he created a world-class kitchen that quickly became famous throughout the city. He realized that engaging the audience wasn't enough; he needed to keep them in order to be profitable. As a result, it provided frequent performances, concerts, and shows for its guests. The aristocrats were attracted here with the help of two prominent members of the National Casino, and his network of contacts played a significant influence in shaping the circle of customers.

\footnotetext{
96 Tarján, V. (1937): 193-194.

97 Kávésok Lapja: Elöljárósági ülés, January 1., 1933. 2.

98 Kávésok Lapja: Elöljárósági ülés, July 3, 1933. 3-4.

99 FL. VII.2.e - Cg.2497 New York Kávéház - 1659. box

1008 órai ujság: Ötszázezer dollárért vette meg a Trieszti Adria Biztosító Társaság a Newyork-palolát, January 24, 1928. 7.

101 Magyarság: Választott bíróság dönt a Newyork-kávéház százhatvanezer pengős bérösszegéről, April 3, 1928.11.

102 Esti Kurír: A Newyork-kávéház száztízezer pengős bérét tíz százalékkal leszállította, February 1, 1930.9.

103 Tarján, V. (1937): 193-194.

104 Ibid 193-194.
} 
His reactions to crises are different. With the help of his business tactics, he was able to successfully deal with the challenges that arose following the First World War. However, his skill has already caught up with the challenges that arose during the Great Depression. He couldn't reach an agreement with the homeowners, and he couldn't use the industry association to assist him combine the growing debts. The most serious issue is that Pest inhabitants' lifestyles and purchasing power have changed. The unfair and unsustainable growth of professional competition was further added to this.

\section{Bibliography}

Buza, P. (2007), Tarján Múvek Részvénytársaság. Egy okos gyerek a pesti éjszakából. In: Buza Péter (Ed.) A bedeszkázott riporter. (Tarján Vilmos’ diary) Budapest: Budapesti Városvédő Egyesület, 5-66.

Csapó, K. (1996), A százéves irodalmi kávéház a „Nerwyork”, Budapesti Negyed, 4. (1996) 179-200.

Czina, S. (2021), The Brief History of the New-York Coffeehouse Company Limited. In:

Kaposi,Z. - Rab, V. (Ed.) Economic and Social Changes: Historical Facts, Analyses and Interpretations, Pécs. 95-104.

Gundel, I. Harmath, J. (1982), A vendéglátás emlékei. Budapest: Közgazdasági és Jogi Könyvkiadó.

Konrádyné Gálos, M. (Ed.) (1965), A Nerwyorktól a Hungáriáig. Budapest: Minerva.

Saly, N. (2001), „Budapest nagykávéház” 2001. november 25 -2002. január 6. Budapest: Ernst Múzeum.

Saly, N. (2008), „Jean becsukta az ablakokat”. A Nyugatés a „nyugatosok” kávéházai. Múlt és Jövő, 69. (2008) $34-46$.

Saly, N. (2016), Tarján Vili babérkoszorúja. Budapest, 13. (2016) No. 1. 23-25.

Sánta, G. (1996), „Vigasztal, ápol és eltakar” A budapesti kávébázak szociológiai és pszichológiai természetrajza századfordulón. Budapesti Negyed, 4. (1996) 29-58.

Szentes, É. - Hargittay, E. (1997), Irodalmi kávébázak Pesten és Budán. Budapest: Universitas Kiadó.

Tarján, V. (1937), (t.v.)-tôl a Tarjánig. Budapest: Pápai Ernő Múintézete

Tarján, V. (1940), A pesti éjszaka. Budapest: Általános Nyomda, Könyv- és Lapkiadó Rt., Vadas, F. (1996), Belsóépitészet és térhasználat a New-Yorkban Budapesti Negyed. 4. (1996) 179-200.

Zeke, Gy. (2001-2002): „Budapest, a kávéváros”. Mikes International 2. (2001-2002) 1024.

\section{Daily Newspapers}

8 órai ujság: Kilenc vöröshaju görl autobuszon Budapest utcáin..., 08 October 192910.

8 órai ujság: Ötszázezer dollárért vette meg a Trieszti Adria Biztosító Társaság a Newyork-palolát, 24 January 19287.

Az Est: Ma estétôl kezdve egy színházzal több játszik Budapesten, 02 October 19308.

BFL. VII.2.e - Cg.2497 New York Kávéház - 1659. box

Budapesti Hírlap: A Newyork-kávéház megnyitása, 25 October 1894

Budapesti Hírlap: Új gazdák a Newyorkban, 17 September 19139.

Esti Kurír: A Newyork-kávéház száztízezer pengős bérét tíz százalékkal leszállította, 01 February 19309.

Kávésok Lapja: A budapesti kávésok fényúzési és forgalmi adóközössége megalakult, 01 February 19281.

Kávésok Lapja: Beköszöntő, 20 October 19251.

Kávésok Lapja: Elöljárósági ülés, 1 December 19312.

Kávésok Lapja: Elöljárósági ülés, 2 January 19332.

Kávésok Lapja: Elöljárósági ülés, 3 July 1933 3-4.

Keleti Ujság: Budapest látványossága: az ujjászületett Newyork, 24 September 19336.

Magyar Kávésipar: A Budapesti Kávésok Áruforgalmi Részvénytársaságának tőkeemelése, 3 July 19203. 
Magyar Kávésipar: A fényűzési adó és a kávéházak, 1 July 19201.

Magyar Kávésipar: A kongresszus, 15 November 19253.

Magyar Kávésipar: A záróra, 1 December 19201.

Magyarország, 11 April 192811.

Magyarország: A legvidámabb szilveszter, 3 January 19286.

Magyarság: Választott bíróság dönt a Newyork-kávéház százhatvanezer pengős bérösszegéről. 03 April 192811.

Pécsi Napló: A Pécsi Napló rádiómúsora, 11 April 193011.

Pesti Hírlap: A legszebb kávéház, 25 October 18949.

Pesti Napló: New-York Budapesten, 14 October 18949.

Vasárnapi Ujság: Newyork palota és kávéháza, 1894. Nr. 46 764-765. 